\title{
CHALLENGES AND SOLUTIONS REGARDING THE QUALITY AND SUPERVISION OF AUDIT DURING THE COVID-19 PANDEMIC
}

\author{
Diana Rencheci*, ORCID ID: 0000-0003-3535-7010 \\ Academy of Economic Studies of Moldova, 61 Banulescu-Bodoni str., Chișinău, Republic of Moldova. \\ ${ }^{*}$ Corresponding author: Diana Rencheci, diana.rencheci@gmail.com
}

Received: 09. 14. 2021

Accepted: 10. 25. 2021

\begin{abstract}
This article addresses the issues faced by auditors, audit firms, and the business environment in the country and abroad, during the Covid-19 pandemic crisis, such as remote work and the issue of communication. At the same time, the author describes the solutions offered by the institutions of different states to overcome this crisis. The problems of the audit and control activity of the banking institutions were addressed, as well as the implementation of some software that would allow performing audit remotely. Solutions for facilitating the lending of entities during this period have also been described. Separately, the issue of contractual relations during the pandemic period was addressed. Using different research methods and analyzing the opinions of different auditors and economists, the author was able to present his own conclusions and recommendations in order to overcome this crisis by both audit firms and state institutions.
\end{abstract}

Keywords: control, crisis, banking sector, remote activity, contract.

Rezumat. În articol sunt abordate problemele cu care se confruntă pe perioada crizei pandemice de Covid-19 auditorii, societățile de audit, precum și mediul de afaceri din țară și de peste hotare, cum ar fi lucrul la distanță și problema comunicării. Totodată, autorul descrie soluțiile oferite de instituțiile diferitor state pentru depășirea acestei crize. Au fost expuse problemele activității de audit și control a instituțiilor bancare, precum implementarea unor softuri ce ar permite auditul la distanță. Au fost descrise soluțiile pentru facilitarea creditării entităților în această perioadă. Separat, a fost abordată problema relaţiilor contractuale în perioada de pandemie. Utilizând diferite metode de cercetare și analizând opiniile diferitor auditori și economiști, autorul a reușit să-și expună propriile concluzii și recomandări în scopul depășirea acestei crize atât de către societățile de audit, cât și de către instituțiile statului.

Cuvinte-cheie: control, criză, sector bancar, activitatea la distanță, contract.

\section{Introducere}

Situațiile de criză economică provocate de pandemii precum cea de Covid-19 sunt imposibil de prognozat, în comparație cu crizele economice ciclice. De aceea, entitățile, inclusiv cele de audit au fost luate prin surprindere de situația creată. Dacă în prima perioadă 
se considera că pandemia va decurge într-un timp scurt, ulterior s-a dovedit a fi mai lungă decât se aștepta. Prin urmare, atât autoritățile publice, cât și mediul de afaceri au întreprins măsuri de a se adapta la noile condiții.

În prezentul articol sunt descrise problemele cu care se confruntă auditorii, societățile de audit, precum și mediul de afaceri în perioada acestei pandemii, dar și soluțiile oferite de către instituțiile diferitor state pentru depășirea acestei crize. Totodată, sunt abordate problemele auditului și controlului în instituțiile bancare, dar și problema relaţiilor contractuale în perioada de pandemie.

Analizând opiniile diferitor auditori și economiști din țară, dar și de peste hotare, care s-au expus asupra problemelor societăților de audit și mediului de afaceri în perioada pandemiei de Covid-19, prin metoda de analiză a documentelor, utilizând diferite surse bibliografice, autorul a reușit o descompunere de conținut a problematicii abordate, ceea ce a permis extragerea de soluții pentru depășirea acestei crize.

Totodată, autorul a utilizat și metoda comparativă, care i-a permis să identifice similitudinile și disimilitudinile existente între practicile naționale și internaționale, dar și metoda sintezei, pentru ca în final să poată să-și expună propriile concluzii și recomandări în scopul depășirii acestei crize atât de către societăților de audit, cât și de către instituțiile statului.

\section{Rezultate și discuții}

Pe perioada pandemiei de Covid-19, din cauza măsurilor de distanțare socială menite să rezolve criza sanitară, entitățile au fost nevoite să implementeze diferite tehnici și practici de operare de la domiciliu. Reieșind din faptul că clienții își exercitau activitatea la distanță, auditorii au fost nevoiți să se adapteze și să se conformeze la situația nou-creată.

Comisia Europeană pentru Supravegherea Asociațiilor Auditorilor subliniază cele mai importante zone care sunt relevante pentru asigurarea calității serviciilor de audit, cum ar fi: colectarea informațiilor suficiente și relevante de audit, continuarea activității, evenimente, raportarea și comunicarea [1, pag. 10].

Auditorul român Făniță menționează că în această perioadă, auditorii întâmpină dificultăți practice, de la accesarea datelor și documentelor clienților până la timpul necesar pentru evaluarea impactului în business a pandemiei. Devine, așadar, necesară adoptarea unor platforme tehnologice care să facă posibilă îndeplinirea misiunilor de audit concomitent cu respectarea principiului distanțării sociale [2, pag. 16].

Reieșind din cele expuse, auditorul român Făniță propune următoarele soluții de comunicare reieșind din figura 1.
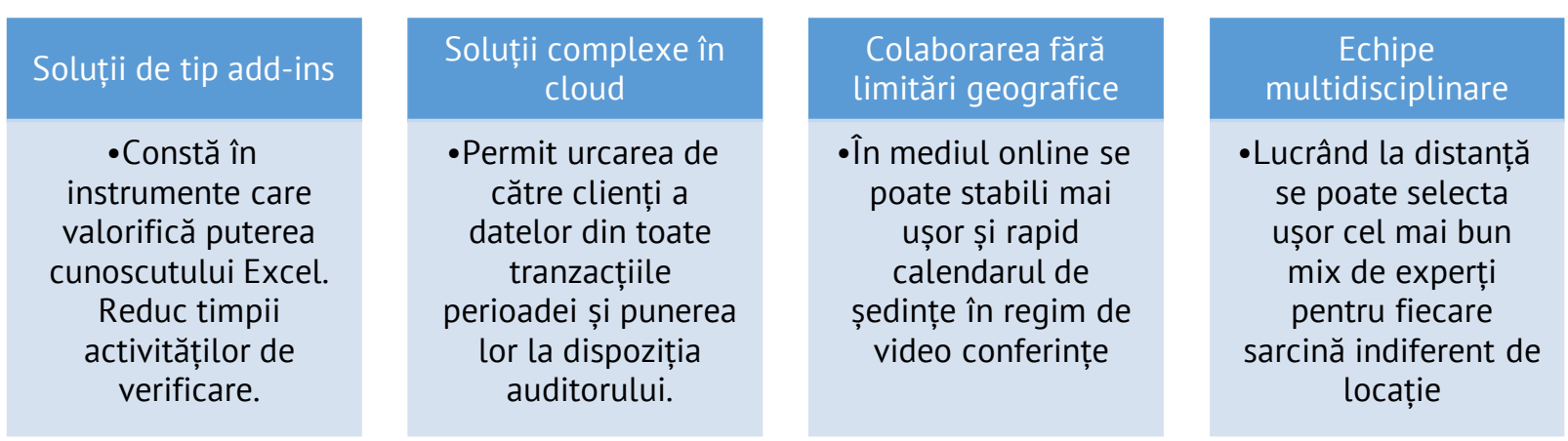

Figura 1. Soluții de comunicare dintre auditori și clienți care permit lucru la distanță. 
Considerăm că este puțin probabil ca pe viitor activitatea de audit să devină complet digitalizată, fără a se produce interacțiunea dintre client și auditor. Chiar dacă tehnologiile informaționale avansează în continuu, totuși credem că interacțiunea fizică este necesară în anumite situații, dar cu păstrarea unor tehnici digitale.

Totuși, în ceea ce privește sectorul de tehnologii, economista Galanton afirmă că entitățile care utilizează pe larg tehnologiile ar suferi cel mai puțin de pandemie. În unele cazuri, au fost semnalate măriri ale cifrei de afaceri în comparație cu aceeași perioadă a anului precedent. Prin urmare, tehnologiile educaționale și rețelele de calculatoare au devenit sectoare cu potențial de creștere. Se preconizează ca aceste sectoare să aibă o evoluție considerabilă în perioada ce urmează, care ar putea schimba complet modul în care gândim despre serviciile virtuale [3, pag. 27].

\section{Auditul bancar în condițiile pandemiei de Covid-19}

Economista rusă din sistemul bancar Efremova consideră că nici sistemul bancar nu a trecut ușor peste perioada de distanțare socială. Aceasta menționează că instituțiile bancare din Federația Rusă nu dispun de condiții tehnice de efectuare a auditului sau controlului intern. De aceea, majoritatea lor au pus pe pauză toate rapoartele de audit, în așteptarea vremurilor mai bune [4, pag. 78].

Prin urmare, aceasta recomandă băncilor comerciale să investească în diferite softuri care ar facilita munca auditorilor și care ar permite obținerea informațiilor necesare și prezentarea rapoartelor de audit într-un regim mai rapid. Însă, din cauza crizei financiare provocate de pandemia de Covid-19, instituțiile bancare au un deficit de lichidități, iar implementarea unor astfel de softuri presupune costuri semnificative. Totuși, aceasta propune următoarele căi de automatizare a procesului de audit bancar:

- dezvoltarea operațiunilor de audit și control intern pentru business-procesele bancare;

- elaborarea sarcinilor tehnice de automatizare a proceselor menționate pentru specialiștii IT;

- testarea programelor de automatizare elaborate și prezentarea rezultatelor testării specialiștilor IT;

- înlăturarea erorilor apărute de către specialiștii IT în urma testării programelor;

- darea în exploatare a programelor și deservirea acesteia [4, pag. 80].

Raportând la situația auditorilor și societăților de audit din Republica Moldova, acestea la fel au avut de suferit cheltuieli semnificative pentru procurarea sau elaborarea de programe informatice pentru a digitaliza procesele în timp record pe perioada distanțării sociale, în același timp confruntându-se cu lipsa de lichidități atât a acestora, cât și a clienților care o perioadă nu au activat și nu au avut venituri.

Potrivit economistei Bejan, expertă în domeniul bancar din Republica Moldova, pentru menținerea stabilității sectorului bancar din Republica Moldova în condițiile pandemiei de Covid-19, Banca Națională a Moldovei (BNM) a întreprins următoarele acțiuni:

- diminuarea ratei de bază aplicată la principalele operațiuni de politică monetară pe termen scurt cu 1,25 puncte procentuale, până la 3,25\% anual, precum și a ratelor de dobândă la creditele și depozitele overnight până la 6,25\% și, respectiv, 0,25\% anual;

- micșorarea cu 2,5 puncte procentuale a normei rezervelor obligatorii, din mijloacele atrase în lei moldovenești și în valută neconvertibilă, până la 38,5\% din baza de calcul, precum și majorarea cu 1,0 puncte procentuale a normei rezervelor obligatorii, din mijloacele atrase în valută liber convertibilă, până la 21,0\% din baza de calcul; 
- susținerea persoanelor fizice consumatori de credite bancare, prin gestiunea flexibilă a obligațiilor debitorilor aflați în dificultate de plată;

- relaxarea cerințelor amortizorului de conservare a capitalului constituit anterior, prin permiterea utilizării temporare a acestuia, pentru a absorbi eventualele înrăutățiri ale calității portofoliului de credit și a sprijini finanțarea mediului de afaceri și a populației [5, pag. 78].

Din cele relatate mai sus, observăm că odată cu declanșarea pandemiei de COVID-19, BNM a depus eforturi în vederea realizării măsurilor de atenuare a impactului unei eventuale crize, ceea ce la fel influențează și societățile de audit, tendință care a fost întâlnită și la nivel internațional. Prin urmare, societățile de audit care au contractat credite, puteau să negocieze termenele contractuale ale acestora. Totodată, BNM a permis băncilor comerciale o supraveghere mai aprofundată a activității clienților săi, pentru a evita situațiile de risc.

\section{Acțiuni și soluții pentru depășirea crizei pandemice la nivel internațional}

Diferite state au acționat diferit pentru a ajuta mediul de afaceri pentru a trece cu succes peste criza financiară provocată de pandemia de Covid-19.

Economista din Federația rusă Sanghinova consideră că cea mai mare problemă a constituit prăbușirea relației dintre cerere și ofertă în această perioadă. Însă, statul rus a ajutat doar business-ul mic cu sume simbolice, pentru susținerea angajaților, nu și entitățile din alte domenii, inclusiv cele din domeniul auditului. Totodată, entităților mici le-a fost rambursat impozitul pe venit achitat pentru anul 2019 [6, pag. 24].

Suedia, singura țară din Uniunea Europeană și una dintre foarte puținele țări ale lumii, care nu a impus nici o restricție, la fel s-a îndreptat spre o recesiune mai mare decât criza financiară din 2008. Totuși, în pofida celor expuse, guvernul suedez a aprobat stimuli fiscali fără precedent, după cum afirmă economistul Dobrescu [7, pag 54].

În cazul Marei Britanii, acest stat se confruntă cu cea mai mare criză economică a țării din ultimii 300 de ani, cauzată de coronavirus. Potrivit unor estimări făcute de Banca Angliei, economia țării va scădea cu 14\% în 2021. Totuși acest stat a elaborat un plan bine structurat de susținere a mediului de afaceri. Prin urmare, după încheierea programului de șomaj tehnic, guvernul Marii Britanii plătește până la două treimi din salariile celor care lucrează cu program redus din cauza noilor restricții impuse în contextul pandemiei. De asemenea, s-a extins programul de suport financiar pentru freelanceri și o reducere de TVA de $15 \%$ a TVAului pentru turism și sectorul de hoteluri, restaurante și catering (HoReCa), precum și ajutor companiilor care trebuie să achite ratele împrumuturilor garantate de guvern [8, pag. 56].

Economistul român Pașa consideră că România se confruntă cu o dereglare importantă a tuturor activităților productive și de servicii cauzată de pandemia de Covid-19. Pentru a depăși această situație, acesta propune următoarele soluții:

- realizarea unui împrumut extern pentru sprijinirea agenților economici să-și continue activitatea fără să renunțe la forța de muncă angajată;

- utilizarea forței de muncă repatriată din diasporă;

- atragerea împrumuturilor de la cetățeni cu dobânzi superioare celor practicate de bănci $[9$, pag. 48].

Considerăm că toate măsurile de redresare a situației economice a țărilor afectate de pandemia de Covid-19 au influențat și activitatea de audit atât direct cât și indirect. Prin urmare, prin compensarea plăților salariale ale celor care au lucrat cu program redus din cauza pandemiei, au fost susținuți direct și angajații companiilor de audit și ai autorităților de control și supraveghere a auditului. Totodată, prin susținerea celorlalte ramuri ale 
economiei, clienții societăților de audit nu se vor confrunta cu lipsa de lichidități și vor putea contracta servicii de audit.

\section{Acțiuni și soluții pentru depășirea crizei pandemice în Republica Moldova}

În ceea ce privește efortul Guvernului Republicii Moldova de a evita o criză economică provocată de efectele pandemiei de Covid-19, economiștii Petroia și Zubcova consideră că acesta s-a axat mai mult pe ajutorul oferit sistemului medical, decât economiei în ansamblu. Prin urmare, anul 2020 a devenit anul cu cea mai mare investiție în sănătate ca procent din PIB din ultimii 3 ani. Pe un fond puternic de instabilitate financiară și posibilă recesiune, sănătatea a devenit prioritară [10, pag. 65].

În opinia noastră, acest fapt este unul inevitabil, însă pe lângă investițiile în sănătate, era necesară o atenție mai mare din partea guvernului și pentru sectorul real pentru menținerea pe linie de plutire a situației economice din țară, iar indirect, și susținerea activității de audit.

Auditorii trebuie să fie informați și despre modificările, ajustările și interpretările din legislația fiscală, care au survenit odată cu pandemia de Covid-19. Auditorul Slobodeanu enumeră mai multe cazuri de acest fel, printre care:

- deductibilitatea testării angajaților din contul angajatorului - Ministerul Finanțelor precum și Serviciul Fiscal de Stat interpretează testarea angajaților de către angajatori ca facilitate acordată de patron, din care urmează a fi calculate toate reținerile ce țin de contribuțiile de asigurări sociale, prime de asistență medicală și impozitul pe venit din salariu. Toate aceste rețineri sunt deductibile în scopuri fiscale, dacă sunt calculate în mod corespunzător;

- cheltuielile/ costurile aferente măștilor, vizierelor, dezinfectanților utilizați în activitatea entităților - pandemia de Covid-19 a forțat includerea în bugetare și planificare a acestor cheltuieli, care anterior nu existau. Organul fiscal recunoaște în totalitate deductibilitatea acestor cheltuieli/ costuri;

- subvenționarea ratei dobânzii - prevede rambursarea de către stat din întreaga sumă sau parțial dobânda acumulată și plătită pentru împrumuturile acordate de sectorul financiar. În legislație se menționează în mod clar că valoarea acestor subvenții este o sursă de venit care nu este supusă impozitului pe venit;

- susținerea activității antreprenoriale și atenuarea consecințelor negative cauzate de situația epidemiologică - entitățile care și-au încetat complet sau parțial activitățile în conformitate cu deciziile Comisiei Naționale Extraordinare de Sănătate Publică și/sau cu ordinele Comisiei pentru Situații Excepționale a Republicii Moldova au dreptul la subvenții în valoarea sumei plătite a impozitului pe venit din salariu, contribuțiile de asigurări sociale și primele de asistență medicală aferente salariilor plătite angajaților care s-au aflat în șomaj tehnic;

- transportul de la locul de reședință la locul de muncă și înapoi prin serviciile companiilor de taxi - acest lucru se face, în primul rând, pentru a minimiza riscul de infectare a angajaților în timp ce se deplasează în transportul public. Legislația fiscală permite deducerea cheltuielilor efectuate pentru transportul organizat al angajaților și anume 35 lei (fără TVA) per angajat pentru fiecare zi lucrată efectiv de angajatul transportat, care a folosit transportul organizat [11, pag. 11].

Considerăm că toate aceste prevederi sunt cunoscute, deoarece ele nu sunt recente. Doar că odată cu situația creată de pandemia de Covid-19, a apărut necesitatea interpretării 
Lor de către organele statului pentru a înțelege modul de reflectare și deducere a lor. Prin urmare, auditorii ar trebui să le cunoască atât pentru activitatea proprie cât și pentru analiza acestor cheltuieli la clienți.

\section{Relaţiile contractuale în perioada de pandemie}

Avocatul Tărîţa descrie și o altă situație problematică provocată de criza pandemică și anume impactul acesteia asupra relaţiilor contractuale. În opinia acestuia, mulţi antreprenori (printre care și auditorii sau societățile de audit) s-au ciocnit cu dificultăţi în executarea obligaţiilor faţă de parteneri pe care şi le-au asumat prin contracte de lungă durată, încheiate până la instituirea de către autorităţi a măsurilor restrictive. În astfel de circumstanţe, inevitabil, a apărut întrebarea dacă pandemia şi măsurile aplicate constituie temei pentru rezoluţiunea sau modificarea obligaţiilor, precum şi pentru scutirea de răspundere pentru neexecutarea lor.

În opinia acestuia, legislaţia naţională prevede trei concepte juridice care pot fi aplicate relaţiilor contractuale în situaţii de criză:

1) justificarea datorită unui impediment (anterior - forţa majoră) - cel mai răspândit eveniment care influenţează prevederile generale cu privire la responsabilitatea părţilor contractante este forţa majoră. Survenirea acestuia îi permite părţii să nu îşi execute obligaţiile asumate prin contract şi, totodată, să-şi limiteze responsabilitatea pentru neexecutare (în cazul respectării unui şir de condiţii).

2) imposibilitatea fortuită de executare - teoretic, coronavirusul şi consecinţele acestuia pot stinge, în genere, obligaţiile contractuale, adică nu doar absolvă de răspunderea pentru neexecutarea lor, cum ar fi în cazul forţei majore. Este important de reţinut că imposibilitatea executării obligaţiei nu trebuie să fie temporară, ci permanentă şi definitivă. Anume imposibilitatea permanentă şi definitivă este principalul criteriu prin care forţa majoră se deosebește de imposibilitatea fortuită de executare.

3) schimbarea excepţională a circumstanţelor - pentru a deosebi forţa majoră de schimbările excepţionale ale circumstanţelor ne vom conduce de următoarea logică. În cazul forţei majore circumstanţa trebuie să blocheze complet executarea obligaţiei şi nu doar să o complice. De exemplu, dacă în urma răspândirii virusului termenul executării obligaţiei se majorează (de exemplu, termenul misiunii de audit) sau dacă în urma instituirii de către autorităţi a măsurilor de interdicţie, societatea de audit nu îşi poate continua activitatea, se va constata schimbarea excepţională a circumstanţelor [12, pag. 74].

Considerăm că forța majoră și schimbarea excepțională a circumstanțelor ar fi cel mai răspândite relații contractuale care ar putea fi aplicate în situația pandemiei de Covid-19, deoarece ele ar fi mai apropiate de domeniul activității de audit. Imposibilitatea fortuită de executare are un caracter definitiv, ceea ce ar împiedica ducerea la bun sfârșit a unei misiuni de audit, în comparație cu celelalte două relații contractuale, care permit finalizarea misiunii cu o anumită modificare a termenelor.

\section{Concluzie}

Activitatea la distanță a devenit o provocare pentru auditori. În perioada de distanțare socială societățile de audit au avut de suferit cheltuieli semnificative pentru procurarea sau elaborarea de programe informatice pentru a digitaliza procesele în timp record, confruntându-se cu lipsa de lichidități atât a acestora, cât și a clienților, care o perioadă nu au activat și nu au avut venituri. Considerăm că este puțin probabil ca pe viitor activitatea de audit să devină complet digitalizată, fără a se produce interacțiunea dintre client și auditor. 
Chiar dacă tehnologiile informaționale avansează în continuu, totuși credem că interacțiunea fizică este necesară în anumite situații, dar cu păstrarea unor tehnici digitale.

Și BNM a depus eforturi în vederea realizării măsurilor de atenuare a impactului unei eventuale crize, ceea ce la fel influențează și societățile de audit. Prin urmare, societățile de audit care au contractat credite, puteau să negocieze termenele contractuale ale acestora. Totodată, BNM a permis băncilor comerciale o supraveghere mai aprofundată a activității clienților săi, pentru a evita situațiile de risc.

În opinia noastră, toate măsurile de redresare a situației economice a țărilor afectate de pandemia de Covid-19 au influențat și activitatea de audit atât direct cât și indirect. Prin urmare, prin compensarea plăților salariale ale celor care au lucrat cu program redus din cauza pandemiei, au fost susținuți direct și angajații companiilor de audit și ai autorităților de control și supraveghere a auditului. Însă în Republica Moldova, cu excepția unor interpretări fiscale în favoarea deductibilității unor cheltuieli, credem că nu au fost aprobate soluții necesare pentru susținerea activității societăților de audit.

Considerăm că forța majoră și schimbarea excepțională a circumstanțelor ar fi cel mai răspândite relații contractuale care ar putea fi aplicate în situația pandemiei de Covid-19, deoarece ele ar fi mai apropiate de domeniul activității de audit.

\section{Bibliografie}

1. Făniţă A. Criza COVID şi auditul financiar. În: Tribuna Economică, 2020, 23, pp. 10-11.

2. Făniţă A. Audit şi consultanţă în economia post-covid. În: Tribuna Economică, 2020, 19, pp.16-17.

3. Galanton N. Impactul pandemiei COVID-19 asupra lanţurilor de aprovizionare. În: Economica, 2020, 3 (113), pp. 21-31.

4. Efremova I. E. Risc-orientirovannii vnutrenii controli v bankah: uroki COVID-19. În: Bankovskoe delo, 2020, 6(316), s. 78-81.

5. Bejan A. Menţinerea stabilităţii sectorului bancar din Republica Moldova în condiţ̧iile pandemiei COVID-19. În: Economica, 2020, 2, pp. 73-83.

6. Sanghinova L.D. Intrumenti gosudarstvennoi finansovoi podderjki subiectov MSP $\vee$ Rossii i za rubejom: pomosi, poderjka, stimul. În: Bankovskoe delo, 2021, 3(325), s. 21-28.

7. Dobrescu E. M. Suedia după coronavirus. În: Tribuna Economică, 2020, 30, pp. 51-56.

8. Dobrescu E. M. Marea Britanie: în şi după pandemie. În: Tribuna Economică, 2021, 5, pp. 50-56.

9. Paşa F. Acţiuni pentru pornirea economiei. În: Tribuna Economică, 2020, 32, pp. 46-49.

10. Petroia A., Zubcova E. Sănătatea şi economia în epoca COVID-19. În: Economica, 2020, 4 (114), pp. 65-75.

11. Slobodeanu S. Nalogovie posledctvia mer i deistvii, vizvonih pandemiei Covid-19. În: Contabilitate şi audit, 2020, 10, s. 11-19.

12. Tăriţ̧a A. Pandemia Covid-19 şi impactul acesteia asupra relaţiilor contractuale. În: Contabilitate şi audit, 2020, 6, p. 74-78. 